\title{
Biological traits and population dynamic of Parapenaeus longirostris (Lucas, 1846) in the Marmara Sea, Turkey
}

\section{Marmara Denizi'nde Parapenaeus Iongirostris (Lucas, 1846)'in biyolojik özellikleri ve populasyon dinamiği}

\author{
Mukadder Arslan İhsanoglư ${ }^{*}$ • Ali İşmen ${ }^{2}$ \\ ${ }^{1}$ Faculty of Marine Sciences and Technology, Department of Fisheries and Processing Technology, \\ Çanakkale Onsekiz Mart University, 17100, Çanakkale, Turkey \\ 2Faculty of Marine Sciences and Technology, Department of Fisheries and Processing Technology, \\ Çanakkale Onsekiz Mart University, 17100, Çanakkale, Turkey

Abstract: Parapenaeus longirostris is a valuable resource for the crustacean fisheries in the Marmara Sea, therefore, in this study length-weight relationships, growth, mortality, reproduction, recruitment patterns, the probabilities of capture and per recruit analyses were determined. Total 36288 samples were collected by beam trawl between September 2011 and July 2014 in 229 sampling stations. The total length (TL), body weight (g) and carapace length (CL) values ranged between $34-175 \mathrm{~mm}, 0.2-28.9 \mathrm{~g}$ and $8-41 \mathrm{~mm}$, respectively. CL-weight relationship equations were calculated for females, males and combined sexes, respectively, $W=0.0023 \times \mathrm{CL}^{2.5}, \mathrm{~W}=0.0029 \times \mathrm{CL}^{2.43}, \mathrm{~W}=0.0022 \times \mathrm{CL}^{2.52}$. The growth parameters were determined as $\mathrm{L}_{\infty}=199.5 \mathrm{~mm}, \mathrm{k}=0.47, \mathrm{t}_{0}=-0.5$ in $\mathrm{TL}$, $L_{\infty}=36.8 \mathrm{~mm}, k=0.37, t_{0}=-0.69$ in $\mathrm{CL}$. $\mathrm{L}_{25}, \mathrm{~L}_{50}$, and $\mathrm{L}_{75}$ values were found to be $15.15 \mathrm{~mm}, 16.29 \mathrm{~mm}, 17.44 \mathrm{~mm}$ for males and $16.62 \mathrm{~mm}, 18.07 \mathrm{~mm}, 19.52$ $\mathrm{mm}$ for females. The sexual maturity length for females was found $27.3 \mathrm{~mm} \mathrm{CL}$ and the exploitation rate was found at 0.62 for the whole population.

Keywords: Parapenaeus longirostris, length-weight relationship, growth, reproduction, stock assessment, Sea of Marmara

Öz: Parapenaeus longirostris, Marmara Denizi'ndeki kabuklu balıkçılık için değerli bir kaynaktır, bu nedenle bu çalışmada uzunluk-ağırlık ilişkileri, büyüme, ölüm, üreme, stoğa katılım modelleri, yakalanma olasılıkları ve stoğa katııım analizleri belirlenmiştir. 229 örnekleme istasyonunda Eylül 2011 ile Temmuz 2014 arasında algarna ile toplam 36288 adet birey toplanmış̦ı. Toplam uzunluk (TL), vücut ağırlığı (g) ve karapaks uzunluğu (CL) değerleri sırasıyla 34-175 mm, $0,2-28,9 \mathrm{~g}$ ve $8-41 \mathrm{~mm}$ arasında değişmiştir. Karapaks boyu-ağırlık ilişkisi denklemleri sırasıyla dişi, erkek ve tüm cinsiyetler için hesaplanmıştır, $W=0.0023 \times C L 2.5, W=0.0029 \times C L^{2.43}, W=0.0022 \times C L^{2.52}$. Büyüme parametreleri toplam boyda $L_{\infty}=199,5 \mathrm{~mm}, k=0,47, t_{0}=-0,5$, karapaks boyunda $L_{\infty}=36.8$ $\mathrm{mm}, \mathrm{k}=0.37, \mathrm{t}_{0}=-0.69$ olarak belirlenmiş̧ir. $\mathrm{L}_{25}, \mathrm{~L}_{50}$ ve $\mathrm{L}_{75}$ değerleri erkekler için $15,15 \mathrm{~mm}, 16,29 \mathrm{~mm}, 17.44 \mathrm{~mm}$ ve dişiler için $16,62 \mathrm{~mm}, 18,07 \mathrm{~mm}, 19,52$ $\mathrm{mm}$ olarak bulundu. Dişiler için ilk eşeysel olgunluk boyu $27,3 \mathrm{~mm} \mathrm{CL}$ ve tüm populasyon için sömürülme oranı 0,62 olarak bulundu.

Anahtar kelimeler: Parapenaeus longirostris, boy-ağırlık ilişkisi, büyüme, üreme, stok değerlendirmesi, Marmara Denizi

\section{INTRODUCTION}

The crustacean fishery has become an important resource for world-wide sea-food markets where crustaceans with claws, spiny lobsters, crabs and penaeid shrimps present high demand. The Deep water rose shrimp Parapenaeus longirostris (Lucas, 1846) has commercially importance in the Mediterranean area especially in Spain, France, Italy, Greece and Tunisia. (Levi et al., 1995; Abello et al., 2002; Deval et al., 2006). The Deep water rose shrimp presents high potential of capture in the marine coasts of Turkey (Zengin et al., 2004; Bayhan et al., 2005; Manaşırlı, 2008) and the $58 \%$ percent of total crustacean production came from the Marmara Sea (TUIK, 2019). However, in recent years the deep water rose shrimp abundance followed a fluctuating. The amount of production is showing a varying trend in the capture volume since 2007 with 2761 t until 2013 with 1620 t, in 20142500 t were captured, after that, decreased to $1764 \mathrm{t}$ and increased again in 2018 with $3212 \mathrm{t}$ (TUIK, 2019). Due to the high commercial value of the shrimps, the actual populations are being caught intensively. Nonetheless, the intensity of catching is decreasing rapidly in the Turkish seas as well as in the whole world. Therefore, the sustainability of shrimp stocks needs to be ensured. In this context, it is required to know the biological parameters of $P$. longirostris to start to clarify the causes in the fluctuation of available populations.

In this study, the Marmara Sea was selected as a principal area of analysis; there were chosen 229 sampling points to record detailed information about length-weight relationship, sex ratio, reproduction period, gonadosomatic index, condition factor, first maturity length, mean length of ages, growth parameters, mortality rates, probability of capture, recruitment pattern, relative $\mathrm{R} / \mathrm{Y}$ and $\mathrm{B} / \mathrm{R}$ analysis of $P$. longirostris. In the 
Marmara Sea there are only a few studies dealing with distribution and biological aspects about $P$. longirostris with few sampling points (Baran and Öztürk, 1990; Zengin et al., 2004; Yazıcı, 2004; Bayhan et al., 2005; Erten, 2009).

On the other hand, in the Mediterranean region several studies have been conducted to study the length-weight relationship (Levi et al., 1995; Garcia-Rodriguez et al., 2009), the reproduction system (Spedicato et al., 1996; Guijarro and Massuti, 2006; Mori et al., 2000; Ben Meriem et al., 2001), the age and growth parameters (Ardizzone et al., 1990; Abello et al., 2002; Ragonese et al., 2002; Kapiris et al., 2013; GarciaRodriguez et al., 2009; Guijarro et al., 2009) in P. Iongirostris . Therefore, in this study we also compare the biological structure of $P$. longirostris on the Mediterranean coasts with the Marmara Sea (length distribution, age, growth parameters and reproduction time) to reveal the stock structure.

To our knowledge there are not previous records about the recruitment pattern, probability of capture, yield-per-recruit $(\mathrm{Y} / \mathrm{R})$ and biomass-per-recruit $(\mathrm{B} / \mathrm{R})$ analysis of $\mathrm{P}$. longirostris in the Sea of Marmara. Therefore, our study becomes in the first detailed work about the length-weight relationship, age, growth and reproduction of $P$. longirostris in the Marmara Sea.

\section{MATERIAL AND METHODS}

\section{Sampling and data collection}

The sampling collection was done in the Marmara Sea, Turkey. Monthly samples of $P$. longirostris were collected in 229 stations from September 2011 to July 2014 (Figure 1). Specimens were caught using a beam trawl with a cod-end mesh size of $32 \mathrm{~mm}$, between 50 and $200 \mathrm{~m}$ depth. In total, 36288 specimens were measured. The carapace length $(C L)$ was recorded with caliper to the nearest $1 \mathrm{~mm}$ taken from the posterior part of the left orbit to the center of the posterior edge of the carapace; total length (TL) was measured with a ruler to the nearest $1 \mathrm{~cm}$ from the tip or the rostrum to the end of the telson; body weight $(\mathrm{g}$ ) was recorded using a digital balance to the nearest $0.01 \mathrm{~g}$.

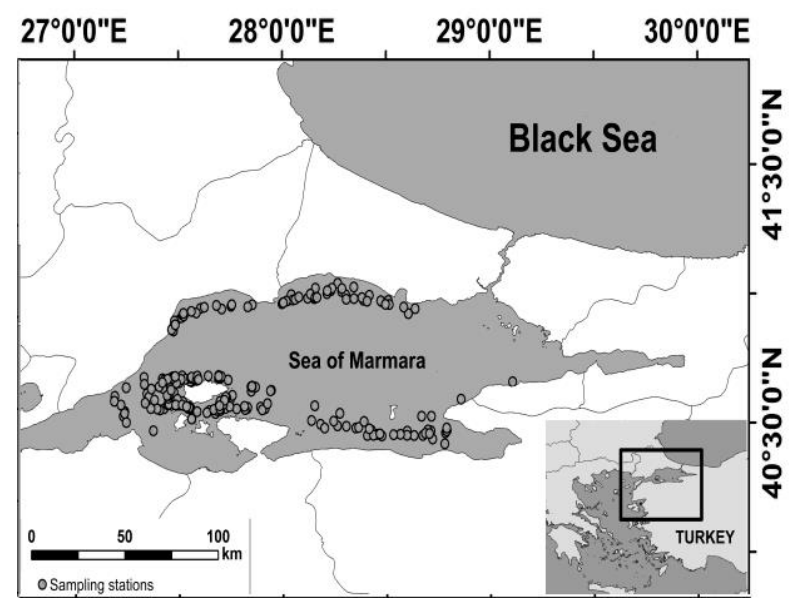

Figure 1. Sampling stations in the Sea of Marmara

\section{Calculation of biological parameters}

Length-weight relationships were calculated considering the allometric equation: $W=a \times L^{b}$, where $L$ is the total length, $W$ is the total weight and $a$ and $b$ are the equation parameters (Sparre et al., 1989). The growth type was defined by using Student's t-test by the equation according to Sokal and Rohlf (1987). Differences between sexes were analyzed with ANCOVA using SPSS16 package program.

The sex-ratio was calculated and compared to the 1:1 proportion using the chi-square $(x 2)$ goodness fit test. Maturity stages were determined using the sexual classification scale of ICES (2009). Five stages were observed. Stage I: immature, stage II: maturing, stage III: mature, stage IV: spawning and stage V: post-spawning. The spawning period was determined through monthly observations of the macroscopic development stages, the condition factor and the gonadosomatic index (GSI). The GSI was calculated as follow: GSI=Gonad weight/Bodyweight) $\times 100$. The condition factor (KF) was calculated in base of Htun-Han (1978)'s formula:

\section{$\mathrm{KF}=(\mathrm{TW}-\mathrm{GW}) / \mathrm{CL} 3^{*} 100$}

TW=total weight $(\mathrm{g}), \mathrm{GW}=$ gonad weight $(\mathrm{g}), \mathrm{CL}=$ Carapace length $(\mathrm{mm})$

The length at which $50 \%$ of specimens were sexually mature $\left(L_{50}\right)$ or length at first maturity was estimated for reproductively active specimens (Stages 3-5) per mm sizeclass, by fitting a logistic function using the Newton algorithm (Microsoft Excel solver routine) which is defined as: $P(1)=1 / 1+e-(a+b 1)$ where $P(1)$ was the proportion of mature specimens at length 1 , and $a$ and $b$ the parameters of the logistic equation (Piñeiro and Saínza, 2003).

Von Bertalanffy growth parameters were calculated $\left.L_{t}=L_{\infty}\left(1-e^{-k(t-t)}\right)\right)$, where the $L_{t}$ is the size at age $t, L_{\infty}$ is the maximum theoretical size, $\mathrm{k}$ is the growth factor, $t_{0}$ is the age at which the size is 0 . Growth parameters ( $L_{\infty}$ and $k$ ), and age analyses were performed on the monthly length distributions for the period 2011-2014 and each sex separately by using the ELEFAN I routine, Bhattacharyya's method (Bhattacharyya, 1967) using the FISAT II automatic calculation program (Gayanilo et al., 2002), to was computed by the equation of Pauly (1984): $\log \left(-\mathrm{t}_{0}\right)=(-0,3932)-0,2752^{*} \log \mathrm{L}_{\infty}-1,038^{*} \log \mathrm{k}$.

For the sake of comparison, the index of overall growth performance $\Phi$, proposed by Pauly \& Munro (1984), was calculated as $\phi=\log \mathrm{K}+2 \log \mathrm{L}_{\infty}$. The natural mortality $(\mathrm{N})$ was obtained using Pauly's empirical formula (Pauly, 1984):

$\operatorname{LnM}=-0.0152-0.279 \times \ln \mathrm{L}_{\infty}+0.6543 \times \operatorname{lnK}+0.463 \times \ln \mathrm{T}$ 
The total mortality (Z) was found using the length converted catch equation (Pauly, 1984). The fishing mortality (F) was calculated by the subtraction of the estimates of $M$ from $Z$.

\section{F=Z-M. The exploitation rate was calculated as follows: E=F/Z}

Recruitment patterns were found from the estimated growth parameters by reflecting the length-frequency data in ELEFAN I The probabilities of capture (LC50) was estimated from the gear selection curve generated from the length converted catch curve. The relative yield per recruit $(Y / R)$ and relative biomass per recruit $(B / R)$ were computed from the ogive selection using the procedure in the FISAT II program (Gayanilo et al., 2002).

\section{RESULTS}

\section{Length-weight relationships (LWRs)}

The $\mathrm{CL}$ for females ranged from 7 to $41 \mathrm{~mm}(\mathrm{n}=15904)$ and for males ranged from 9 to $35 \mathrm{~mm}(\mathrm{n}=20384)$. The mean $\mathrm{CL}$ was $24.07 \mathrm{~mm}( \pm 4.34)$ for females, $20.66 \mathrm{~mm}( \pm 2.66)$ for males and $22.58 \mathrm{~mm}( \pm 4.07)$ for the combined sexes (Figure 2).



Figure 2. Length frequency distribution of $P$. longirostris in the Sea of Marmara

The $\mathrm{CL}$ and weight values were determined yearly and seasonally, the values did not present statistical differences between seasons and years $(p>0.05)$. CL-weight relationships were separately estimated for females, males and combined. The length-weight relationship equation for female, male and sexes combined was calculated as $W=0.0023^{*} \mathrm{CL}^{2.5}$, $W=0.0029^{*} C^{2.43}, W=0.0022^{*} C^{2.52}$, respectively. The results for the $\mathrm{CL}$-weight relationships according to the sex indicates a negative allometric growth $(b<3$; t-test, $P<0.05)$. And there was a statistically significant difference among the estimated parameters between the two sexes $(p<0.05$, ANCOVA).

\section{Reproduction}

The sex ratio proportion was found 1:1.3 (M: F). The females represented the $55.8 \%$ and the males the $44.2 \%$ of the analyzed population. The sex ratio proportion did not present statistical differences from 1:1 proportion $(p>0.05$, $x 2)$.

The monthly changes in the condition factor (KF) and GSI values for females are indicated in Figure 3. The KF values were low for summer and autumn, but were high in the spring. The observed changes in the GSI diagram showed that GSI values varied in opposite trend respect to KF values.

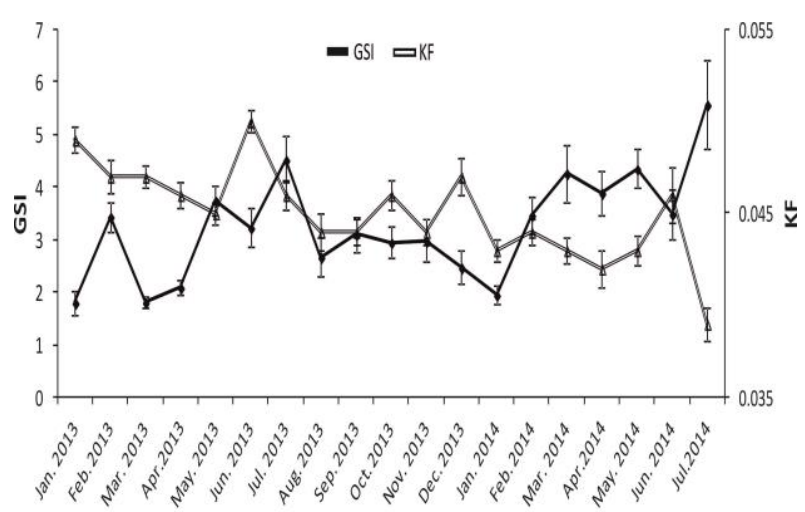

Figure 3. Monthly changes in GSI and KF values

The maturity process was classified in five stages. Each analyzed month presented the III and IV stages (which include mature individuals); on the other hand, during summer and autumn III, IV and V were the most frequent observed stages (Figure 4). The three years of monthly analyses indicates that changes in maturity stages, KF and GSI showed that reproduction of $P$. longirostris continued throughout the year with a peak of maturity during summer in the Marmara Sea. The size in which individuals reach $50 \%$ maturity was determined at $27.3 \mathrm{~mm} \mathrm{CL}$ (Figure 5).

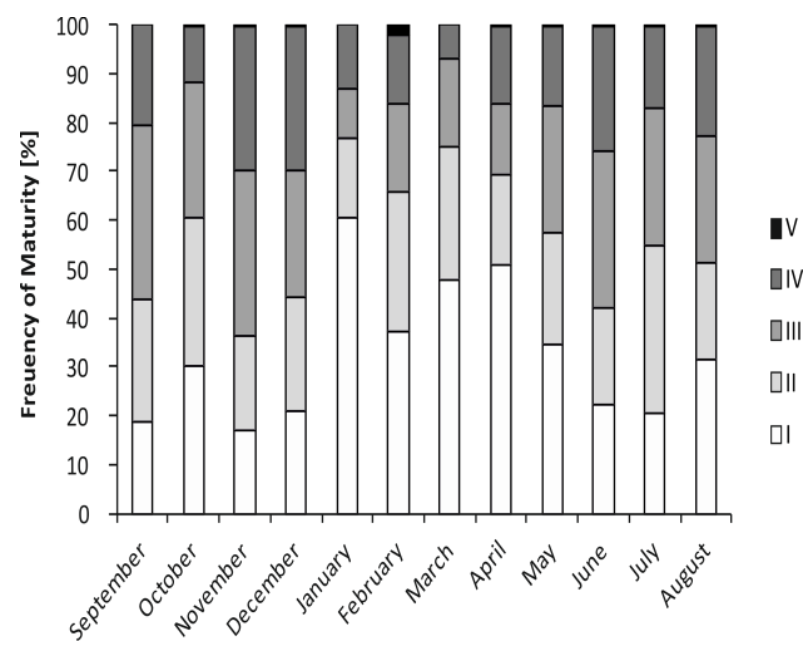

Figure 4. Monthly changes in reproductive stages of $P$. longirostris 


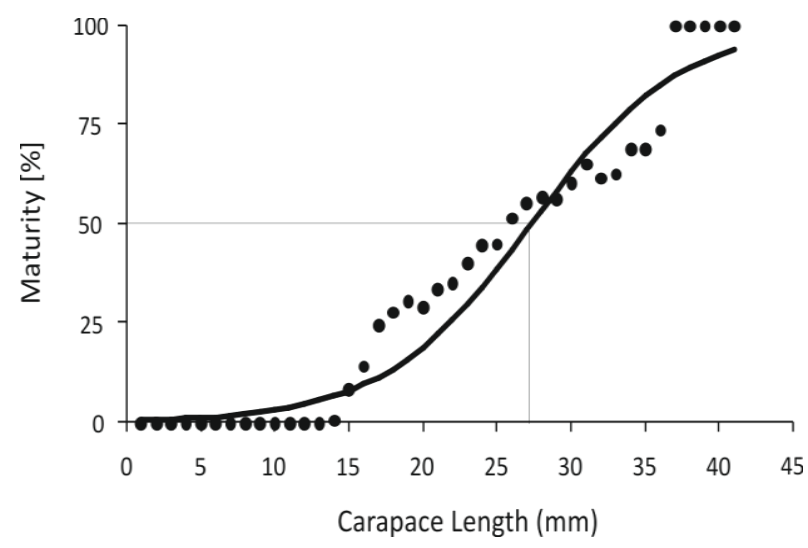

Figure 5. The first maturity length of $P$. longirostris $(\mathrm{CL})$

\section{Growth}

The growth parameters were determined as $L_{\infty}=41 \mathrm{~mm}$, $\mathrm{K}=0.27$ year $^{-1}, \mathrm{t}_{0}=-0.78$ year in females, $\mathrm{L}_{\infty}=36.8 \mathrm{~mm}, \mathrm{~K}=0.37$ year $^{-1}, t_{0}=-0.69$ year in males and $L_{\infty}=42 \mathrm{~mm}, K=0.35$ year $^{-1}$, $\mathrm{t}_{0}=-0.69$ year for the combined sexes. The mean lengths were calculated for every age group. The maximum age was calculated as 4 for females and 3 for males (Table 1).

\section{Mortality rates}

The mortality rates were calculated separately for females, males, and total population. According to the calculated results of $\mathrm{M}, \mathrm{Z}, \mathrm{F}$ and $\mathrm{Ec}$ the values were $0.52,1.09,0.57,0.52$ in females; 0.66, 2.22, 1.56, 0.70 in males and 0.61, 1.60, 0.99, 0.62 in the total population, respectively.

Table 1. Age-carapace length key for female, male and combined sexes of $P$. Iongirostris

\begin{tabular}{cccc}
\hline \multirow{2}{*}{ Ages } & \multicolumn{3}{c}{ Calculated Mean Length } \\
\cline { 2 - 4 } & Female & Male & Total \\
\hline 1 & $17.6 \pm 0.7$ & $16.5 \pm 2.4$ & $13.9 \pm 3.4$ \\
2 & $26.2 \pm 0.7$ & $21.2 \pm 1.1$ & $21.1 \pm 2.9$ \\
3 & $33.0 \pm 0.6$ & $25.6 \pm 2.5$ & $26.7 \pm 2.7$ \\
4 & 38.7 & - & 33.9 \\
\hline
\end{tabular}

\section{Probability of capture}

The probability of capture values $L_{25}, L_{50}$, and $L_{75}$ were found to be $16.62 \mathrm{~mm}, 18.07 \mathrm{~mm}, 19.52 \mathrm{~mm}$ for females and $15.15 \mathrm{~mm}, 16.29 \mathrm{~mm}, 17.44 \mathrm{~mm}$ for males, respectively (Figure 6). (a) Probability of Capture

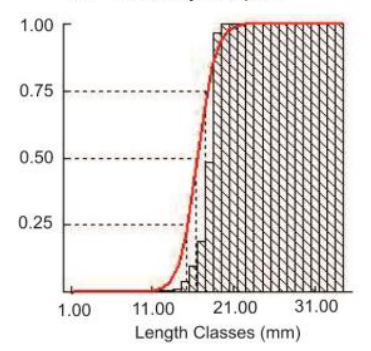

(b) Probability of Capture

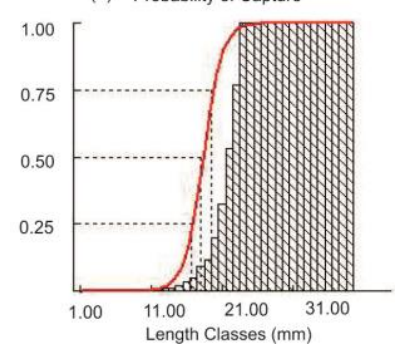

Figure 6. Probabilities of capture for males and females of P. longirostris

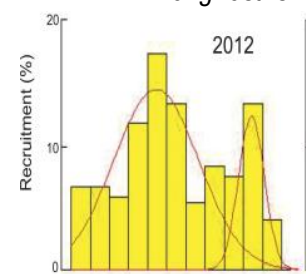

One year

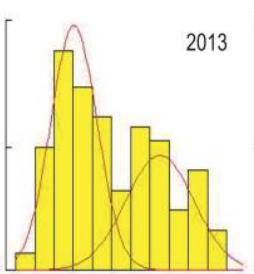

One year

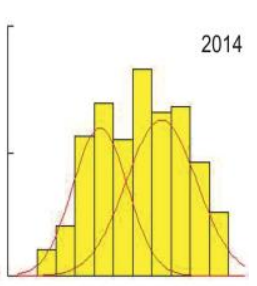

One year
Figure 7. Recruitment patterns according to years

\section{Recruitment pattern and Exploitation parameters}

The recruitment patterns showed two annual pulses of recruitment during the three years of analysis. The recruitment peaks seem to occur in February and June in 2012, October and March in 2013, December and March in 2014 (Figure 7).

The relative $Y / R$ and $B / R$ analysis of the $P$. longirostris were estimated using the selection ogive procedure of FISAT II software (Figure 8 ). The required parameters that $\mathrm{LC}_{50} / \mathrm{L}_{\infty}$ and $\mathrm{M} / \mathrm{K}$ ratios of 0.49 and 1.78 for males and 0.53 and 1.93 for females were used as the input parameters for the analysis. $\mathrm{LC}_{50} / \mathrm{L}_{\infty}$ of less than 0.5 indicates that small-sized shrimps are dominated for males, as distinct from females $L C_{50} / L_{\infty}$ equal to 0.5 . The analysis indicated the exploitation rates $E_{\max }, E_{50}$ and $E_{10}$ as $0.74,0.36,0.60$ for males and $0.75,0.37,0.62$ for females, respectively. The $Y / R$ and $B / R$ were found to be 0.02 , 0.35 for females and $0.03,0.34$ for males.

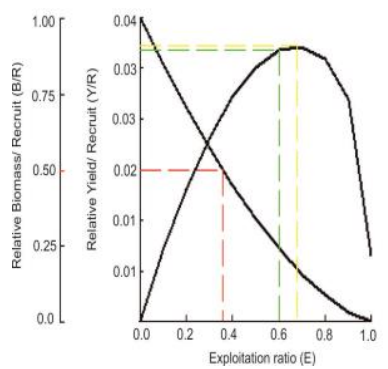

Figure 8. Relative $Y / R$ and $B / R$ using selection Ogive for male (a) and female (b)

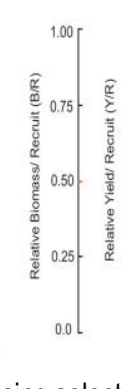

(b)

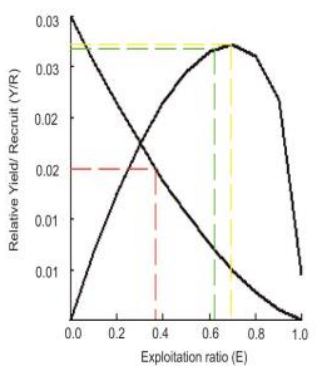




\section{DISCUSSION}

\section{Length-weight relationships (LWRs)}

The carapace length-weight relationship equations of $P$. longirostris were calculated for females, males and combined sexes respectively. The results pointed to negative allometry.
These results were similar to the other studies in the Marmara Sea, (YazıcI, 2004; Zengin et al., 2004; Bayhan et al., 2005; Erten, 2009). Additionally, studies in the Aegean Sea and Mediterranean coasts have reported also negative allometry for the $P$. longirostris growth (Table 2).

Table 2. Length-weight relationship parameters reported in Mediterranean region and the Sea of Marmara (present study)

\begin{tabular}{|c|c|c|c|c|c|c|}
\hline Author & Area & Sex & $\mathbf{N}$ & a & b & $\mathbf{R}^{2}$ \\
\hline Levi et al., 1995 & Sicilian Channel & $\mathrm{M}+\mathrm{F}$ & & 0.0060 & 2.27 & \\
\hline \multirow[t]{3}{*}{ Garcia-Rodriguez et al., 2009} & Alicante Bay & M & 4948 & 0.0029 & 2.48 & 0.91 \\
\hline & & $\mathrm{F}$ & & 0.0024 & 2.56 & 0.96 \\
\hline & & $\mathrm{M}+\mathrm{F}$ & & 0.0020 & 2.61 & 0.96 \\
\hline Demirci and Hoşsucu, 2007* & North Eastern Mediterranean & $\mathrm{M}+\mathrm{F}$ & 100 & 1.8709 & 1.84 & \\
\hline \multirow[t]{3}{*}{ Manaşıllı, 2008* } & Babadillimanı Bay & $\mathrm{M}$ & 923 & 0.0015 & 2.62 & 0.91 \\
\hline & & $\mathrm{F}$ & 2859 & 0.0009 & 2.82 & 0.96 \\
\hline & & $M+F$ & 3886 & 0.001 & 2.79 & 0.95 \\
\hline \multirow[t]{3}{*}{ Tosunoğlu et al., 2009} & Sığacık Bay & $\mathrm{M}$ & 1313 & 0.0001 & 2.76 & 0.94 \\
\hline & & $\mathrm{F}$ & 2456 & 0.0001 & 2.84 & 0.95 \\
\hline & & $M+F$ & 3768 & 0.0001 & 2.83 & 0.95 \\
\hline \multirow[t]{3}{*}{ Dereli, 2010* } & Aegean Sea & $\mathrm{M}$ & 1313 & 0.0012 & 2.69 & 0.94 \\
\hline & & $\mathrm{F}$ & 2456 & 0.0012 & 2.70 & 0.95 \\
\hline & & $M+F$ & 3768 & 0.0012 & 2.70 & 0.95 \\
\hline \multirow{2}{*}{ Yazıcı, 2004} & Marmara Sea & $M$ & 1073 & 0.0112 & 2.59 & 0.93 \\
\hline & & $\mathrm{F}$ & 869 & 0.0057 & 2.95 & 0.97 \\
\hline \multirow[t]{3}{*}{ Zengin et al., 2004} & Marmara Sea & $\mathrm{M}$ & 1964 & 0.0093 & 2.70 & 0.91 \\
\hline & & $\mathrm{F}$ & 2483 & 0.0059 & 2.93 & 0.95 \\
\hline & & $M+F$ & 4447 & 0.0053 & 2.97 & 0.95 \\
\hline \multirow[t]{3}{*}{ Bayhan et al., 2005} & Marmara Sea & $\mathrm{M}$ & 1076 & 0.0059 & 2.86 & 0.96 \\
\hline & & $\mathrm{F}$ & 2679 & 0.0034 & 3.13 & 0.98 \\
\hline & & $M+F$ & 3755 & 0.0031 & 3.16 & 0.97 \\
\hline \multirow[t]{3}{*}{ Erten, 2009} & Marmara Sea, Islands & $\mathrm{M}$ & & 0.0551 & 1.94 & 0.77 \\
\hline & & $\mathrm{F}$ & & 0.0105 & 2.69 & 0.42 \\
\hline & & $M+F$ & & 0.0121 & 2.61 & 0.73 \\
\hline \multirow[t]{3}{*}{ This study* } & Marmara Sea & $\mathrm{M}$ & 15904 & 0.0029 & 2.43 & 0.89 \\
\hline & & $\mathrm{F}$ & 20384 & 0.0023 & 2.50 & 0.94 \\
\hline & & $M+F$ & 36288 & 0.0022 & 2.52 & 0.94 \\
\hline
\end{tabular}

*analyzed with $\mathrm{CL}$

\section{Reproduction}

The monthly condition factor varied between 0.47 and 0.50 . The lowest KF for $P$. longirostris was observed in summer and early autumn (August-October) and the highest value in spring (April) (Figure 3). According to the monthly changes of GSI value the reproductive period of $P$. longirostris correspond with the summer periods in the Marmara Sea.

Zengin et al. (2004) reported that in the Marmara Sea the shrimp population showed intensive breeding throughout the year, the females lay their eggs in two separate periods during the year. The authors specified the periods during spring, early summer and Autumn, respectively. In the Mediterranean coasts and the Aegean Sea the reproduction is intense during November, December and February (Bayhan et al., 2005), April to June (Manaşırlı, 2008) and November to August (Guijarro and Massuti, 2006). The first sexual maturity in this study was found to be larger than the previous studies (Table 3). The differences between studies are because reproductive activity occurs at different times according to geographical areas. 
Table 3. Reproductive season and first maturity length reported in Mediterranean region and the Sea of Marmara (present study)

\begin{tabular}{|c|c|c|c|}
\hline Author & Area & $\begin{array}{l}\text { Reproductive } \\
\text { Time }\end{array}$ & $\begin{array}{l}\text { First reproductive } \\
\text { length }(\mathrm{mm})\end{array}$ \\
\hline Spedicato et al., 1996 & South Tiran Sea & & $28.4(\mathrm{CL})$ \\
\hline Mori et al., 2000 & Tiran Sea & & $22(\mathrm{CL})$ \\
\hline Ben Meriem et al., 2001 & North Tunisian & & $20.1(C L)$ \\
\hline Guijarro and Massuti, 2006 & Balear Island & $\begin{array}{l}\text { November } \\
\text { August }\end{array}$ & $28(\mathrm{CL})$ \\
\hline Manaşırlı, 2008 & Babadillimanı Bay & December -June & $18.2(\mathrm{CL})$ \\
\hline Tosunoğlu et al., 2009 & Sığacık Bay & Autumn - Spring & $26.13(\mathrm{CL})$ \\
\hline Dereli, 2010 & Aegean Sea & & $24.56(\mathrm{CL})$ \\
\hline Zengin et al., 2004 & Marmara Sea & Spring & $106.1(\mathrm{TL})$ \\
\hline Bayhan et al., 2005 & Marmara Sea & Sep., Oct.-Dec.-Apr.-May & $97(\mathrm{TL})$ \\
\hline Zengin and Tosunoğlu, 2006 & Marmara Sea & Summer-Autumn & $97(\mathrm{TL})$ \\
\hline This study & Marmara Sea & Summer & $\begin{array}{l}27.3(\mathrm{CL}) \\
126(\mathrm{TL})\end{array}$ \\
\hline
\end{tabular}

\section{Growth}

The growth parameters are given in Table 4. The calculated growth performance index $(\phi)$ was 2.70 for males, 2.66 for females and 2.79 for both sexes. The growth parameters of $P$. longirostris population were compared with previous reported studies (Table 4). Whole data were analyzed using Munro's Fi Test and presented statistical significant differences $(p<0.05)$. Although the calculation method is the same about growth parameters, differences in study results may have been effective in regional differences, sample numbers, sex, and ecological factors. The maximum age calculated for $P$. longirostris in the Marmara Sea in this study was 4 years in case of females and 3 years in case of males.
Other studies reported a maximum of 6 years in the Aegean Sea (Tosunoğlu et al., 2009). Around 4 and 3 years in the Mediterranean region, respectively (Demirci and Hoşsucu, 2007; Manaşırlı, 2008). One study conducted previously in the sea of indicated 3 years age of the shrimp (Zengin et al., 2004).

\section{Mortality rates}

In Table 5 are shown the analyzed mortality rates wich presented significant differences with studies that were conducted in the Mediterranean region. According to our results, $P$. longirostris population showed overfishing pressure, these results are similar to other studies carried out in the Turkish waters (Tosunoğlu et al., 2009; Deval et al., 2006; Manaşırlı, 2008).

Table 4. Growth parameters obtained by different authors for $P$. longirostris in the Mediterranean region and the Sea of Marmara (present study)

\begin{tabular}{|c|c|c|c|c|c|c|c|}
\hline Author & Area & Sex & $\mathrm{TL}_{\infty}$ & $\mathrm{CL}_{\infty}$ & $\mathrm{K}$ & $t_{0}$ & $\phi$ \\
\hline \multirow{2}{*}{ Ardizzone et al., 1990} & \multirow{2}{*}{ Tiran Sea } & $M$ & - & 33.1 & 0.93 & 0.05 & 3.01 \\
\hline & & $\mathrm{F}$ & - & 44.4 & 0.74 & 0.13 & 3.16 \\
\hline Levi et al., 1995 & Sicilian Channel & $\mathrm{M}+\mathrm{F}$ & - & 30.5 & 0.63 & 0.190 & 2.77 \\
\hline Abello et al., 2002 & Mediterranean & $M+F$ & - & 47 & 0.49 & - & 3.03 \\
\hline \multirow{2}{*}{ Ragonese et al., 2002} & \multirow{2}{*}{ Sicilian Channel } & M & - & 34.3 & 0.73 & \multirow{2}{*}{ - } & 2.93 \\
\hline & & $\mathrm{F}$ & - & 40.9 & 0.71 & & 3.07 \\
\hline \multirow{2}{*}{ Kapiris et al., 2013} & \multirow{2}{*}{ Ionian Sea } & $M$ & - & 33.2 & 0.68 & \multirow{2}{*}{ - } & 2.87 \\
\hline & & $\mathrm{F}$ & - & 37.2 & 0.76 & & 3.02 \\
\hline \multirow{2}{*}{ Garcia-Rodriguez et al., 2009} & \multirow{2}{*}{ Alicante Bay } & $M$ & - & 36 & 0.49 & 0.075 & 2.81 \\
\hline & & $\mathrm{F}$ & - & 47 & 0.44 & 0.134 & 2.99 \\
\hline
\end{tabular}


Biological traits and population dynamic of Parapenaeus longirostris (Lucas, 1846) in the Marmara Sea, Turkey

\begin{tabular}{|c|c|c|c|c|c|c|c|}
\hline & & $\mathrm{M}+\mathrm{F}$ & - & 45 & 0.39 & 0.102 & 2.90 \\
\hline & & $\mathrm{M}$ & - & 31.3 & 1.0 & 0.49 & 2.99 \\
\hline \multirow[t]{2}{*}{ Guijarro et al., 2009} & \multirow[t]{2}{*}{ Balearic Island } & $\mathrm{F}$ & - & 44 & 0.67 & 0.21 & 3.11 \\
\hline & & $M+F$ & - & 40 & 0.84 & 0.49 & 3.13 \\
\hline \multirow{3}{*}{ Manaşılı, 2008} & \multirow{3}{*}{ Babadıllimanı Bay } & $M$ & - & 31.2 & 0.76 & 0.39 & 2.87 \\
\hline & & $\mathrm{F}$ & - & 32.3 & 0.77 & 0.39 & 2.90 \\
\hline & & $\mathrm{M}+\mathrm{F}$ & - & 32.1 & 0.76 & 0.39 & 2.89 \\
\hline Demirci and Hoşsucu, 2007 & Mediterranean & $\mathrm{M}+\mathrm{F}$ & - & 34.6 & 0.480 & 1.010 & 2.76 \\
\hline \multirow{2}{*}{ Bilgin et al., 2009} & \multirow{2}{*}{ Saros Bay } & $\mathrm{M}$ & - & 27.0 & 1.49 & 0.88 & 3.04 \\
\hline & & $\mathrm{F}$ & - & 34.7 & 1.05 & 0.95 & 3.10 \\
\hline \multirow{3}{*}{ Tosunoğlu et al., 2009} & \multirow{3}{*}{ Sığacık Bay } & $\mathrm{M}+\mathrm{F}$ & - & 42 & 0.5 & - & 2.95 \\
\hline & & $\mathrm{M}$ & - & 34.99 & 0.41 & 1.016 & 2.70 \\
\hline & & $\mathrm{F}$ & - & 41.26 & 0.31 & 1.039 & 2.73 \\
\hline Baran and Öztürk, 1990 & Marmara Sea & - & 147 & - & - & - & - \\
\hline \multirow{2}{*}{ Zengin et al., 2004} & \multirow{2}{*}{ Marmara Sea } & $M$ & 157.9 & - & 0.380 & 1.422 & 3.98 \\
\hline & & $\mathrm{F}$ & 170.2 & - & 0.581 & 0.962 & 4.23 \\
\hline \multirow{3}{*}{ This study } & \multirow{3}{*}{ Marmara Sea } & M & - & 36.8 & 0.37 & 0.69 & 2.70 \\
\hline & & $\mathrm{F}$ & - & 41 & 0.27 & 0.78 & 2.66 \\
\hline & & $M+F$ & - & 42 & 0.35 & 0.69 & 2.79 \\
\hline
\end{tabular}

Table 5. Reported natural mortality $(\mathrm{M})$, fishery mortality $(\mathrm{F})$, total mortality $(\mathrm{Z})$ and exploitation rate $(\mathrm{Ec})$ of $P$. longirostris in the different areas and the Sea of Marmara (present study)

\begin{tabular}{|c|c|c|c|c|c|c|}
\hline Author & Area & Sex & M & $F$ & $\mathbf{Z}$ & Ec \\
\hline Levi et al., 1995 & $\begin{array}{l}\text { Kelibia and } \\
\text { Lampedusa }\end{array}$ & & & & 1.239 & \\
\hline Abello et al., 2002 & South Aegean & $\mathrm{M}+\mathrm{F}$ & & & 3.22 & \\
\hline Abello et al., 2002 & North Aegean & $\mathrm{M}+\mathrm{F}$ & & & 2.41 & \\
\hline Ragonese et al., 2002 & Scilian Channel & $\begin{array}{l}\mathrm{M} \\
\mathrm{F}\end{array}$ & $\begin{array}{l}1.30 \\
1.20\end{array}$ & & $\begin{array}{l}3.33 \\
3.37\end{array}$ & \\
\hline Baran and Öztürk, 1990 & Marmara Sea & & & & 5.2 & \\
\hline Zengin et al., 2004 & Marmara Sea & $\mathrm{M}+\mathrm{F}$ & 0.85 & 1.06 & 1.91 & 0.50 \\
\hline Demirci and Hoşsucu, 2007 & $\begin{array}{l}\text { Northern East } \\
\text { Mediterranean }\end{array}$ & $M+F$ & 1.29 & 0.34 & 1.635 & 0.21 \\
\hline Deval et al., 2006 & Sea of Marmara & $\begin{array}{l}M \\
F \\
M+F\end{array}$ & 0.97 & $\begin{array}{l}1.86 \\
1.57 \\
0.60\end{array}$ & $\begin{array}{l}2.83 \\
2.13 \\
1.16\end{array}$ & $\begin{array}{l}0.65 \\
0.54 \\
0.38\end{array}$ \\
\hline Manaşırlı, 2008 & Babadillimanı Bay & $\begin{array}{l}M \\
F \\
M+F\end{array}$ & $\begin{array}{l}1.31 \\
1.29 \\
1.29\end{array}$ & $\begin{array}{l}3.86 \\
2.12 \\
2.71\end{array}$ & $\begin{array}{l}5.17 \\
3.41 \\
4.00\end{array}$ & $\begin{array}{l}0.74 \\
0.62 \\
0.67\end{array}$ \\
\hline Bilgin et al., 2009 & Saros Bay & $\begin{array}{l}M \\
F\end{array}$ & $\begin{array}{l}3.51 \\
4.73\end{array}$ & & $\begin{array}{l}0.88 \\
1.19\end{array}$ & \\
\hline Tosunoğlu et al., 2009 & Sığacık Bay & $\begin{array}{l}M \\
F \\
M+F\end{array}$ & $\begin{array}{l}0.67 \\
0.77 \\
0.77\end{array}$ & $\begin{array}{l}0.54 \\
1.71 \\
1.18\end{array}$ & $\begin{array}{l}1.21 \\
2.48 \\
1.95\end{array}$ & $\begin{array}{l}0.45 \\
0.69 \\
0.60\end{array}$ \\
\hline This study & Marmara Sea & $\begin{array}{l}M \\
F \\
M+F\end{array}$ & $\begin{array}{l}0.66 \\
0.52 \\
0.61\end{array}$ & $\begin{array}{l}1.56 \\
0.57 \\
0.99\end{array}$ & $\begin{array}{l}2.22 \\
1.09 \\
1.60\end{array}$ & $\begin{array}{l}0.70 \\
0.52 \\
0.62\end{array}$ \\
\hline
\end{tabular}




\section{Probabilities of capture}

The probability of capture L50 was referred as the length at first capture, in females the $L c / L \infty$ ratio revealed that this ratio was 0.5 inferior to males. This result indicated that catches were dominated by small individuals. The $L 50$ values were smaller than the length at first maturity (27.3). Therefore, overfishing of non-mature individuals could be a first sight of declining populations in the Marmara Sea.

\section{Recruitment pattern and exploitation parameters}

The recruitment patterns showed that there are two peaks each year, those recruitment peaks seem to occur in February and June in 2012, October and March in 2013, December and March in 2014 (Figure 7). The recruitment of new specimens has been in the winter seasons.

Our result of the relative $Y / R$ and $B / R$ analysis for the stock of $P$. longirostris showed overexploitation for males and exploitation within safe limits for females. Levi et al. (1995) presented an exploitation rate $\mathrm{Ec}=0.8$ bigger than the

\section{REFERENCES}

Abello, P., Abella, A., Adamidou, A., Jukic-Peladic, S. \& Maiorano P. (2002). Geographical patterns in abundance and population Structure of Nephrops norvegicus and Parapenaeus longirostris (Crustacea: Decapoda) along the European Mediterranean coasts. Scientia Marina, 66 (2), 125-141.

Ardizzone, G.D., Gravina, M.F., Belluscio, A. \& Schintu P. (1990). Depth-size distribution pattern of Parapenaeus longirostris (Lucas, 1846) (Decapoda) in the central Mediterranean Sea. Journal of Crustacean Biology, 10 (1), 139-147. DOI: $10.2307 / 1548677$

Baran, İ. \& Öztürk, B. (1990). Marmara Bölgesinde Yoğun olarak Bulunan Parapenaeus longirostris (Lucas, 1846) Crustacea: Decapoda Üzerinde Silivri-Tekirdağ Arasındaki Bölgede Stok Çalışmaları. Tubitak Project Report, No VAGH-717, 86 pp.

Bayhan, K., Unluer, T., Akkaya, M. (2005). Some biological aspects of Parapenaeus longirostris (Lucas, 1846) (Crustacea, Decapoda) inhabiting the Sea of Marmara. Turkish Journal of Veterinary and Animal Sciences, 29, 853-856.

Ben Meriem, S., Fehri-Bedoui, R. \& Gharbi, H. (2001). Taille à Maturation et Période de Ponte de la Crevette Rose, Parapenaeus longirostris (Lucas, 1846) de Tunisie. Crustaceana, 74 (1), 39-48.

Bhattacharyya, P. K. (1967). Efficient Estimation of a Shift Parameter From Grouped Data. The Annals of Mathematical Statistics, 38 (6), 1770-1787. DOI: 10.1214/aoms/1177698611

Bilgin, S., Özen, O., İşmen, A. \& Özekinci, U. (2009). Bathymetric distribution, seasonal growth and mortality of the deep-water rose shrimp Parapenaeus longirostris (Decapoda:Penaeidae) in an unexploited stock in Saros Bay, Aegean Sea. Journal of Animal and Veterinary Advance, 8 (11), 2404-2417.

Demirci, A. \& Hoçsucu H. (2007). Kuzeydoğu Akdeniz'de Derin Deniz Pembe Karidesinin (Parapenaeus longirostris) Populasyon Yapısı ve Yoğunluğu. Türk Sucul Yaşam Dergisi, 3-5 (5-8), 50-55.

Dereli, H. (2010). Sığacık Korfezi'nde Dip Trol Ağları İle Yakalanan Derin Su Pembe Karidesi (Parapenaeus longirostris Lucas, 1846)'nin Bazı Biyolojik ve Populasyon Özellikleri. PhD Thesis, Ege University, Turkey, 158 pp.
$E_{\max }=0.67, E_{0.5}=0.41, E_{0.1}=0.66$ in the Central Mediterranean in the late 1980's. After that, in the late 1990's the overfishing was confirmed by IRMA-CNR (1999) in the Strait of Sicily. According to GFCM report the P.Iongirostris population has overexploitation (FAO, 2015).

In conclusion, our study provided new knowledge of the population parameters and stock assessment of $P$. Iongirostris in the Marmara Sea, where is important to understand the differences/similarities or changes in biological properties and management/sustainable production of this valuable species.

\section{ACKNOWLEDGMENT}

This study is a part of the Ph.D. thesis as 'Spatial-Temporal Variations in Population Structure, Abundance and Catch Rates of Parapenaeus longirostris (Lucas, 1846) in The Sea of Marmara' and financially supported by TAGEM project no: TAGEM / HAYSÜD / 2011 / 09 / 02 /04. And the authors would like to thanks the staff who helped in the laboratory and the fieldwork.

Deval, M. C., Ateş, C., Bök, T. \& Tosunoğlu, Z. (2006). The Effect of Mesh Size and Cod End Material on the Mortality and Yield of the Rose Shrimp, Parapenaeus longirostris (Lucas, 1846) (Decapoda, Penaeidae) in the Turkish Beam Trawl Fishery. Crustaceana, 79 (10), 1241-1249. DOI: 10.1163/156854006778859533

Erten, M. (2009). Marmara Denizi'nde Manyat Avcllı̆ı İle Karides (Parapenaeus longirostris Lucas, 1846) Avcılığının Araştırıması. MSc Thesis, Istanbul University, Turkey, $90 \mathrm{pp}$.

Garcia-Rodriguez, M., Perez Gil, J.L. \& Barcala, E. (2009). Some biological aspects of Parapenaeus longirostris (Lucas, 1846) (Decapoda, Dendrobranchiata) in the Gulf of Alicante (S.E. Spain). Crustaceana, 82, 293-310. DOI: 10.1163/156854009X409108

Gayanilo, F. C., Sparre, P. \& Pauly, D. (2002). The FAO - ICLARM stock Assessment Tools (FISAT-II) User's guide. Computerized Information series. FAO, Rome, Italy.

FAO (2015). General Fisheries Commission for the Mediterranean. Report of the sixteenth session of the Scientific Advisory Committee. St. Julian's, Malta, 17-20 March 2014. FAO Fisheries and Aquaculture Report. No. R1102, Rome, 250 pp.

Guijarro, B. \& Massuti, E. (2006). Selectivity of diamond- and square-mesh codends in the deepwater crustacean trawl fishery off the Balearic Island (western Mediterterranean). ICES Journal of Marine Science, 63, 52-67. DOI: 10.1016/j.icesjms.2005.08.011

Guijarro, B., Massuti, E., Moranta, J. \& Cartes, J.E. (2009). Short spatiotemporal variations in the population dynamics and biology of the deep water rose shrimp Parapenaeus longirostris (Decapoda: Crustacea) in the western Mediterranean. Scientia Marina, 73, 183-197. DOI: $10.3989 /$ scimar.2009.73n1183

Htun Han, M. 1978. The reproductive biology of the dab Limanda limanda (L.) in the North Sea: gonosomatic index, hepatosomatic index and condition factor. Journal of Fish Biology, 13, 369-378. DOI: 10.1111/j.1095-8649.1978.tb03445.x

ICES, 2009. Report of the Workshop on crustaceans (Aristeus antennatus, Aristaeomorpha foliacea, Parapenaeus longirostris, Nephrops norvegicus) maturity stages (WKMSC). ICES CM 2009/ACOM, No 46, 77 pp. 
IRMA-CNR, 1999. Valutazione delle risorse demersali nello Stretto di Sicilia (Mar Mediterraneo) nell'ambito del piano quadriennale 1996-99: rapporto finale vol. 1-2. Gruppo Nazionale Valutazione Risorse Demersali (GRUND), Unità Operativa $n^{\circ} 11$, IRMA-CNR, Mazara del Vallo (TP), Italy, 97pp.

Kapiris, K., Markovic, O., Klaoudatos, D. \& Djurovic, M. (2013). Contribution to the Biology of Parapenaeus longirostris (Lucas, 1846) in the South lonian and South Adriatic Sea. Turkish Journal of Fisheries and Aquatic Sciences, 13, 647-656. DOI: 10.4194/1303-2712-v13_4_10

Levi, D., Andreoli, M. G. \& Giusto, R. M. (1995). First assessment of the Rose Shrimp, Parapenaeus longirostris (Lucas, 1846) in the Central Mediterranean. Fisheries Research, 21 (3-4), 375-393. DOI: 10.1016/0165-7836(94)00298-B

Manaşırlı, M. (2008). Babadillimanı Koyu'ndaki (Silifke-Mersin) Derin Su Pembe Karidesinin (Parapenaeus longirostris Lucas, 1846) Biyo-Ekolojik Özellikleri ve Populasyon Dinamiği Parametreleri. PhD Thesis, Cukurova University, Turkey, $125 \mathrm{pp}$.

Mori, M., Sartor, P. \& Biagi, F. (2000). Diet of Adult Females of Parapenaeus longirostris (Crustacea, Decapoda) in the Northern Tyrrhenian Sea (western Mediterranean). Atti Società Toscana di Scienze at Naturali, 107, 7-10.

Pauly, D. (1984). Fish Population Dynamics in Tropical Waters: A Manual For Use With Programmable Calculators. ICLARM Stud. Rev. 8. 325 p.

Pauly, D. \& Munro, J.L. (1984). Once More on the Comparison of Growth in Fish and Invertebrates. ICLARM Fishbyte, 2, 21.

Pineiro, C. \& Sainza, M. (2003). Age estimation, growth and maturity of the european hake (Merluccius merluccius (Linnaeus, 1758)) from Iberian Atlantic waters. ICES Journal of Marine Science. 60, 1086-1102. DOI: 10.1016/S1054-3139(03)00086-9
Ragonese, S., Andreoli, M.G., Bono, G., Giusto, G.B. \& Rizzo, P. (2002). Overview of the Available Biological Information on Demersal Resources of the Strait of Sicil. Medsudmed Technical Documents, No 2, 6774 pp.

Sokal, R.R. \& Rohlf, F.J. (1987). Introduction to biostatistics. New York Freeman, $352 \mathrm{pp}$.

Sparre, P., Ursin, E. \& Venema, S.C. (1989). Introduction to tropical fish stock assessment. FA0 Fish Tech Pap, 306/1, 407 pp.

Spedicato, M.T., Lembo, G., Silecchia, T.E. \& Carbonara, P. 1996. Distribuzione e Biologia di Parapenaeus longirostris (Lucas, 1846) Nel Tirreno Centro-Meridionale. Biolgia Marina Mediterranea, 3, 579-581.

Tosunoğlu, Z., Akyol, O., Dereli, H. \& Yapici, S. (2009). Sığacık Körfezi'nde Dip Trol Ağları ile Yakalanan Derin Su Pembe Karidesi (Parapenaeus longirostris Lucas, 1846)'nin Bazı Biyolojik ve Populasyon Özelliklerinin Araştırıması. TUBiTAK Project Report, No 108Y102, 156 pp.

TUiK, 2019. Su Ürünleri İstatistikleri Mikro Veri Seti. Türkiye İstatistik Kurumu, Ankara.

Zengin, M. \& Tosunoglu, M. (2006). Selectivity of diamond and square mesh beam trawl cod ends for Parapenaeus longirostris (Lucas, 1846) (Decapoda, Penaeidae) in the Sea of Marmara. Crustaceana, 79 (9), 1049-1057. DOI: 10.1163/156854006778859713

Zengin, M., Polat, H., Kutlu, S., Dinçer, C. \& Güngör H. (2004). Marmara Denizi'ndeki Derin Su Pembe Karidesi (Parapenaeus longirostris, Lucas, 1846) Balıkçılığının Geliştirilmesi Üzerine Bir Araştırma. No TAGEM/HAYSUD/2001/09/02/004, Tarım ve Köy İşleri Bakanlığı Su Ürünleri Merkez Araştırma Müdürlüğü, Trabzon, 211p.

Yazici, M.F. (2004). Karides Avcılığında Kullanılan Algarnaların Av Kompozisyonu ve Hedeflenmeyen Ava Ait Bir Çalışma. MSc Thesis, Canakkale Onsekiz Mart University, Turkey. 69 pp. 